\title{
Introduction of the American Pediatric Society's 2016 John Howland Award Recipient, Barbara J. Stoll, MD
}

Lucky Jain ${ }^{1}$

$F_{\mathrm{r} m a}^{\mathrm{e}}$ ew pediatricians have risen high enough in the academic ranks to become Dean of a major US medical school, fewer opportunities of this magnitude happen to women. The legacy of Dr. Barbara Stoll is truly hard to summarize in these short few paragraphs. Her impact on pediatrics spans decades of dedicated service as a neonatologist, researcher, educator, department Chair, Institute of Medicine member, American Pediatric Society President, and now Dean of McGovern Medical School of the University of Texas Health Sciences Center at Houston. It is indeed my singular honor to introduce this year's John Howland Awardee, Dr. Barbara J. Stoll (Figure 1).

Barbara was born and raised in New York and while she has spent much of her adult life in the southeast, she still considers herself a New Yorker. Her father was a physician who loved medicine, loved life, and loved his family. Her mother was a great intellectual and a voracious reader and spoke (yes!) seven languages. Barbara graduated from the Bronx High School of Science, a school that is famed for the highest number of Nobel Laureates in the country. From there, she went to Barnard College and then to Yale Medical School. Her residency training in pediatrics was at Columbia Presbyterian and neonatology fellowship at Emory in Atlanta. During these formative years of her career, Barbara credits her professional development to many mentors: Patricia Farnsworth, a biologist who taught her the art of balancing roles of a rigorous academician with that of a feminine woman, wife, and mother; Peter Juviler, a political scientist and scholar of the former Soviet Union who infused in his students a love for teaching; Marty Lorin, Richard Behrman, Michael Katz, Stanley James, John Driscoll and Rich Polin, who helped shape her academic career; Andy Nahmias who showed her the excitement of discovery; and finally $\mathrm{Al}$ Brann from whom Barbara learned of true commitment to mothers and babies everywhere.

Barbara met the love of her life, Roger Glass, when she was $19 \mathrm{y}$ old and in college and was married in her final year of medical school (Figure 2). Roger is an incredibly smart, curious, and brilliant scientist who is full of adventure and understands the greater meaning of life. They are both highly accomplished and immensely respectful of each-other's career journeys. Together, they have raised a wonderful family of caring individuals (Figure 3).
So what makes Barbara Stoll great and deserving of one of the highest honors in pediatrics? Barbara is a neonatologist with a mission to improve the health and lives of mothers and babies throughout the world. After completing her neonatology fellowship at Emory in 1979, she began her career as an Associate Scientist at the International Centre for Diarrhoeal Disease Research in Bangladesh, where she was introduced to the problems of child survival in developing countries. It was here that she Barbara was instrumental in starting the Dhaka Hospital Surveillance system that is still active today after over 35 y (1)! In her first US academic position as a Research Assistant Professor in the Department of Medicine and Pediatrics, Uniformed Services University of the Health Sciences, Bethesda, MD, she worked in a basic science infectious disease laboratory and developed her clinical skills as an attending in the nursery. In 1986, she joined the Emory University Department of Pediatrics and has devoted herself not only to the health of mothers and babies (Figure 4), through clinical care advancement and research. At an individual, institutional, and national/international level, few academicians in pediatrics have had a broader impact on research and scholarship than Barbara. She has authored over 250 peerreviewed manuscripts and too-numerous-to-count editorials, review articles and book chapters. She is recognized as one of the strongest leaders in the NICHD Neonatal Network for clinical trials and served as a center PI for nearly $25 \mathrm{y}$ ! During this time, Barbara has played a pivotal role as a long-standing member of the Network Steering Committee, Chair of the Very-Low-Birth-Weight data registry, and member of the NICHD Collaborative Stillbirth Network. Her seminal work on neonatal sepsis has paved the way for uniform guidelines for clinical care and has impacted neonatal mortality worldwide (2-6). In addition, Barbara has mentored dozens of trainees and faculty and has taken scholarship at the Emory University Department of Pediatrics to dizzying heights.

As Department Chair, Barbara led the transformation of the Emory Department of Pediatrics from one that had primarily regional recognition and a very limited research portfolio, to a vibrant nationally and internationally recognized destination department with outstanding clinical services, training programs, and cutting-edge research. In the $10 \mathrm{y}$, Barbara 


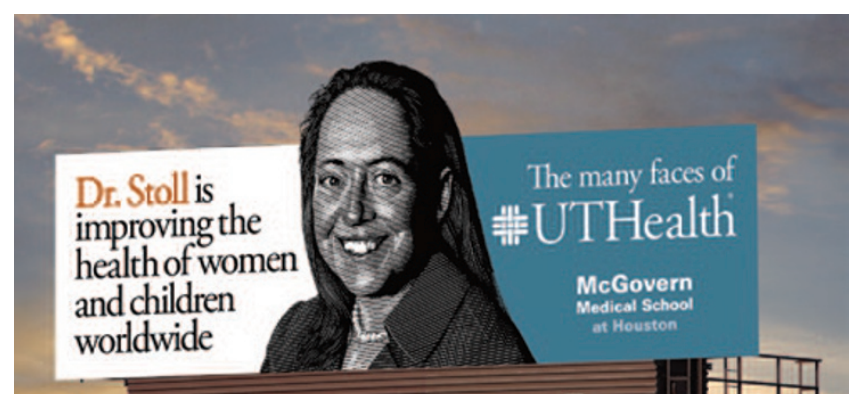

Figure 1. Barbara J Stoll MD, Wayne Hightower Distinguished Professor and Dean, University of Texas McGovern Medical School featured on a billboard in Houston.

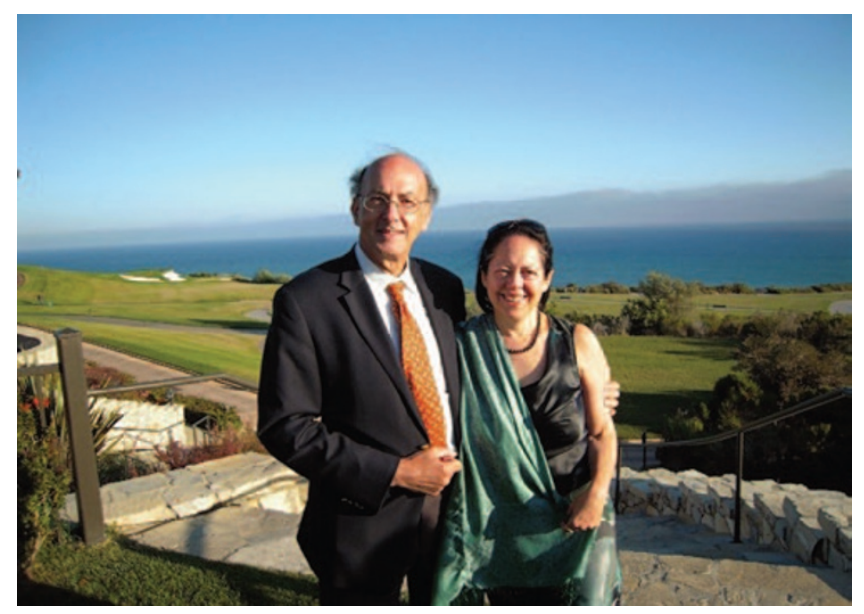

Figure 2. Dr. Barbara Stoll with her husband, Dr. Roger Glass, who is head of the Fogarty International Center at the National Institutes of Health. Both are elected members of the Institute of Medicine.

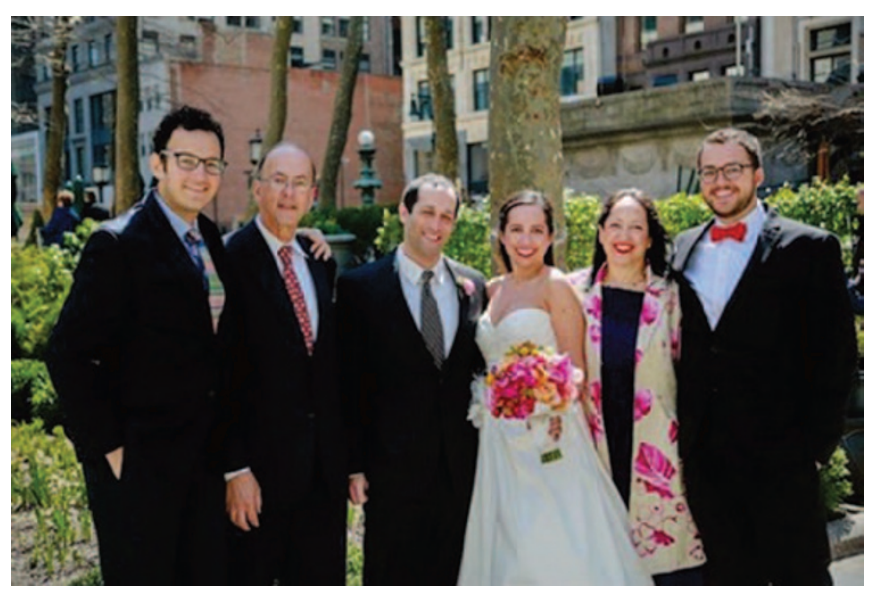

Figure 3. Dr. Barbara Stoll's family of caring individuals.

held the position of Chair in the Department of Pediatrics, we saw a nearly fivefold increase in total extramural grant funding (ended FY2015 at approximately \$59M) and an eightfold increase in NIH funding. The Department now ranks second at Emory's SOM in total extramural grant funding. The National Institutes of Health ranking of the Department of Pediatrics moved from 49th when Barbara took over as Chair to 6 th this past year. In building the national stature of the

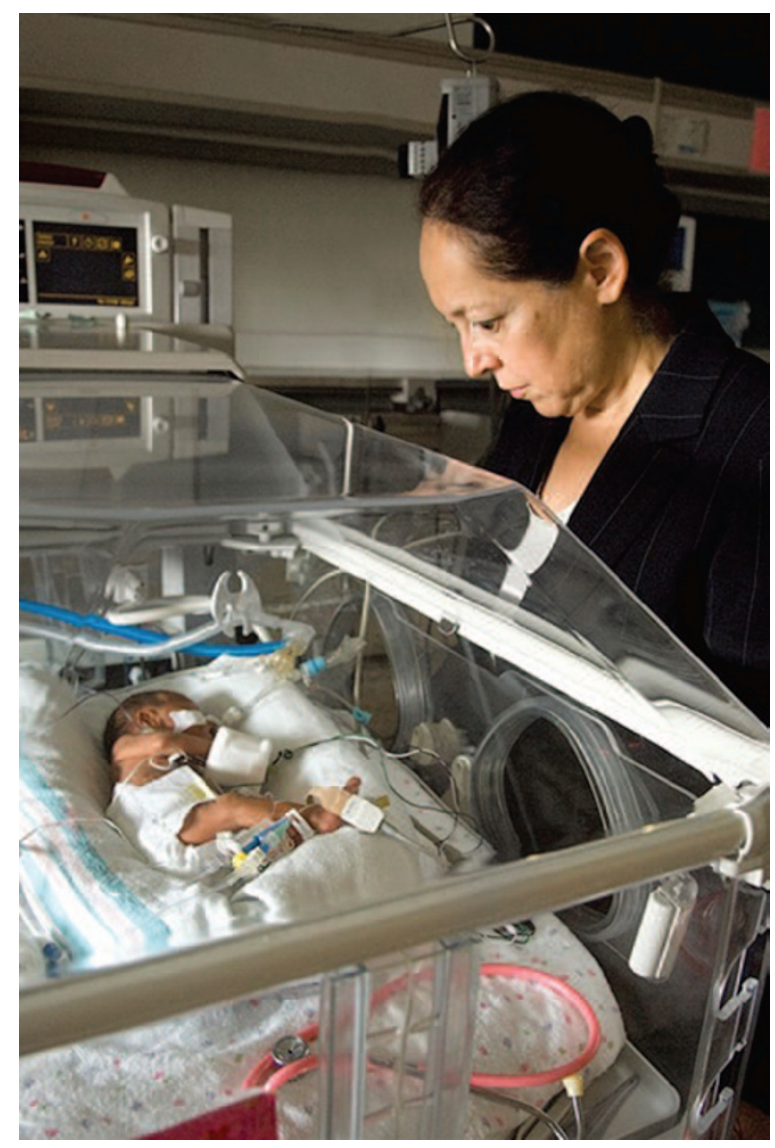

Figure 4. Dr. Stoll, the neonatologist, with a patient in the neonatal intensive care unit.

Department, she also enhanced the stature and national recognition of Children's Healthcare of Atlanta and of Emory's School of Medicine and University.

Barbara is a remarkable role model for young trainees and academic faculty. She always makes herself available to meet with trainees and faculty and delights in helping others build their academic careers. An articulate supporter of women and minorities, she is a particularly important role model for young women who haven't had the opportunity to learn from the careers and lives and women in senior leadership roles. She has served as a tireless advocate for our students/ trainees, faculty, programs, and for the children and families we serve.

As her leadership roles increased and her time spent offering direct clinical care has decreased, Barbara has never lost sight of her mission and goal to care for others and has remained an active and strong advocate for children. She served on the Board of the Georgia Chapter of the American Academy of Pediatrics for $12 \mathrm{y}$ and kept herself engaged in a number of local and national activities to lobby on behalf of children. She has served as a member of the Council of the American Pediatric Society for a number of years and as the American Pediatric Society President-elect and President. As a senior child health leader, she has worked with the American Academy of Pediatrics to participate in legislative visits on Capitol Hill in DC to discuss 


\section{Special Article}

issues of importance to children-access to healthcare and enhancing pediatric training and child health research.

Barbara's love for global medicine is deep rooted and is reflected in her overseas work in several countries, as well as her advocacy for global health activities within US academic programs. Barbara started her career while working in Bangladesh for $4 \mathrm{y}$, learning about issues of global child survival and mortality, the importance of diarrheal and respiratory diseases, of malnutrition, and of maternal and newborn health and wellbeing. As a mid-career faculty member she spent a sabbatical year at the World Health Organization where she spearheaded efforts to understand the causes of neonatal mortality in developing countries, the contribution of neonatal mortality to overall under- 5 child mortality, and to develop interventions to improve survival. She was part of the senior Emory leadership team that designed a global health strategic plan for Emory's School of Medicine. Almost 10 y ago, the Emory Department of Pediatrics established a relationship with the Aga Khan University in Pakistan to accept their medical students each year for rotations in pediatrics. Due in large part to Barbara's vision, support and commitment, the department has a growing global health program. Global Health Organization of Pediatrics at Emory supports institutional relationships with a number of other overseas sites such as Ethiopia and Brazil and sponsors a global health curriculum and global health tract for our pediatric residents and other trainees.

Barbara is passionate when she describes recruitment of outstanding faculty as perhaps the most important and rewarding jobs of an academic department chair. She excels at identifying talented faculty candidates and enjoys the success of recruiting them. During her time as Chair, Emory's Department of Pediatrics grew from a faculty of 160 to approximately 411 clinical and research faculty. She was instrumental in recruiting a large number of clinical scholars and leaders to build our subspecialty divisions - to meet the subspecialty needs of our community and to build strong academic training and research programs. Her skill lies not only in recruitment, but in finding that "right fit" and in helping ensure the career development, mentoring, and recognition of her faculty.

Barbara has been recognized at Emory with the Albert E. Levy Award for the best scientific publication of the year and with the Unsung Heroine Award of the Emory Center for Women. She was also named an Atlanta Business to Business Woman of Excellence in 2010 and has been among the Atlanta
Business Chronicle’s Top 100 in Healthcare since 2010. For her many academic and leadership contributions, she has been recognized nationally with election to the prestigious Institute of Medicine of the National Academy of Sciences and is a past President of the American Pediatric Society (the oldest and most influential pediatric academic society in the country).

The list of her accomplishments goes on but in the end what truly differentiates Barbara is not her academic prowess but her humility, caring, and ability to give. She truly believes in fair and just culture, being kind to each-other and practicing random acts of kindness. David Stevenson noted in his nomination letter that "Barbara is quite simply an academic giant, quiet, unassuming, but always with a firm resolve to advance the cause. Her $\mathrm{CV}$ is a tome of academic and professional accomplishments. She is exactly the kind of person who should be honored by the John Howland Award and does indeed bring much honor to the award".

\section{ACKNOWLEDGMENT}

The author would like to thank Hal Simon, Howard Bauchner, David Stevenson, Steve Miller, and Rita Ryan for their support of Stoll's nomination.

\section{REFERENCES}

1. Stoll BJ, Glass RI, Huq MI, Khan MU, Holt JE, Banu H 1982 Surveillance of patients attending a diarrhoeal disease hospital in Bangladesh. BMJ (Clinical Research Ed.) 285:1185-88

2. Stoll BJ, Hansen N, Fanaroff AA, et al. Changes in pathogens causing earlyonset sepsis in very-low-birth-weight infants. N Engl J Med 2002;347: 240-7.

3. Stoll BJ, Hansen N, Fanaroff AA, et al. Late-onset sepsis in very low birth weight neonates: the experience of the NICHD Neonatal Research Network. Pediatrics 2002;110(2 Pt 1):285-91.

4. Stoll BJ, Hansen NI, Adams-Chapman I, et al.; National Institute of Child Health and Human Development Neonatal Research Network. Neurodevelopmental and growth impairment among extremely low-birth-weight infants with neonatal infection. JAMA 2004;292:2357-65.

5. Stoll BJ, Hansen NI, Bell EF, et al.; Eunice Kennedy Shriver National Institute of Child Health and Human Development Neonatal Research Network. Neonatal outcomes of extremely preterm infants from the NICHD Neonatal Research Network. Pediatrics 2010;126:443-56.

6. Stoll BJ, Hansen NI, Sánchez PJ, et al.; Eunice Kennedy Shriver National Institute of Child Health and Human Development Neonatal Research Network. Early onset neonatal sepsis: the burden of group B Streptococcal and E. coli disease continues. Pediatrics 2011;127:817-26.

7. Stoll BJ, Hansen NI, Bell EF, et al.; Eunice Kennedy Shriver National Institute of Child Health and Human Development Neonatal Research Network. Trends in care practices, morbidity, and mortality of extremely preterm neonates, 1993-2012. JAMA 2015;314:1039-51. 